\title{
Caliphate Redefined: The Mystical Turn in Ottoman Political Thought
}

HüseyinYılmaz

Princeton: Princeton University Press, 2018, 384 pages.

ISBN 9780691174808

Hüseyin Yilmaz's Caliphate Redefined: The Mystical Turn in Ottoman Political Thought, the product of many years of research, is a seminal work in the history of Ottoman political thought. The book focuses on Ottoman political thought during the reign of Süleyman I (1520-1566) but connects this period more broadly with the rise of mystical conceptions of political authority in the post-Abbasid era. To do this, the author creatively and uniquely examines and engages in many different genres and texts that were "limited to Rumi expositions of political thought that include Ottoman authors who either dedicated their works to the sultan or lived in the core provinces of Asia Minor and the Balkans" (p. 10). Moreover, the author takes the intellectual exchanges between this cultural geography and the wider cultural geographical expanse that has been recently dubbed the "Balkans-to-Bengal Complex"1 and argues that the mystical turn, which mainly indicates a Sufistic tone in the post-Abbasid era, gave shape to Ottoman political thought from the very beginning of the state to the end of the sixteenth century.

In chapter one, Yilmaz surveys Ottoman political literature from its foundations in the early fifteenth century to the late sixteenth century, tracing the trajectory of Ottoman political thought. He divides writings on politics into four types: statecraft, ethical, juristic and Sufistic. The author presents the last of these as a distinctive category within Ottoman political thought, concerning Sufi perspectives on rulership during the age of Süleyman (p. 66). In spite of the existence of these four ways, the works from each tradition on politics were mainly written either from distinctly Sufi traditions or by authors who had a close relationship with Sufism and used Sufistic language even in their other political writings.

One of the watershed moments in the history of the caliphate, according to Yilmaz, is the collapse of the Abbasid caliphate due to the Mongol invasion in the mid-thirteenth century. He argues that the historical caliphate as a form of universal political leadership (p. 182), which supposes one state's

1 Shahab Ahmed, What is Islam: The Importance of Being Islamic, Princeton University Press, 2016, pp. 37-48. 
hegemony over all Muslims, ended with the emergence of multiple individual states within the Islamic lands. The de facto situation precluded a caliphate based on the juristic perspective which required one unique caliph who is of "Qurayshi" descent and khalifat Rasūl Allāh (the Prophet's successor). In chapter two, "The Caliphate Mystified," Yllmaz examines the emergence and development of the Sufistic form of caliphate-which does not require any of the above-mentioned requirements of the juristic perspective-from the formal end of the Seljuk state to the Egyptian campaign in 1516-1517. This caliphate provides the ruler with a legitimacy-based claim to universal leadership by linking him directly to God as khalifat Allāh (God's vicegerent). In this chapter, he shows the presence of both notions of the caliphate in Anatolia during the beglik period. He describes this period as the formative period of Ottoman political thought due to the emergence and transformation of concepts such as dawla (a divinely granted auspicious turn in power) and the blurred boundaries between rulers and Sufis in their titles, namely Çelebi, Hüdavendigar and Emir (pp. 111-23).

In chapters three and four, the author discusses the conception of the nature of authority. In the chapter, "The Sultan and the Sultanate," the raison dêtre of the Sultanate is explained by quoting various author opinions that understood political authority as representing an innate human need. Furthermore, he discusses the ways to become a ruler under three possible categories: grace (nima), merit (istihqāq), and subjugation (qahr)—or a combination of these. In the next chapter, "The Caliph and the Caliphate," the author narrows the scope to Islamic origins of authority by highlighting the archetypical perfect ruler and the relationship between the notions of a caliphate and a sultanate. He elaborates the transition of the rulership ideal from the prophet's successor to God's vicegerent by the hands of Sufis with the decline of juristic political thought in the post-Mongol period. In particular, he shows the role of the schools of Ibn 'Arabì and Ishräqiyya in helping to shape the Ottoman understanding of the caliphate as a combination of spiritual and temporal authority. Furthermore, he emphasizes that the Sufi understanding of the caliphate also made it possible for other actors, such as Sufis, to claim unified authority. (p. 202).

In the final chapter, Hüseyin Yllmaz insightfully historicizes and contextualizes the aforementioned theoretical insights. He traces "the myth of the Ottoman Caliphate" throughout Ottoman history. Starting with the Ottoman ruler Bayezid's defeat by Timur in 1402, Ottoman political thought was shaped by encounters with rival ideologies and cultures. He describes the sixteenth century as a self-reliant period of the empire by considering the 
proliferation of Turkish treatises and attributing importance of the dynasty as a legitimizing factor by various writers. More importantly, he argues that the Ottoman-Safavid conflict was not just a sectarian but also an apocalyptic conflict, in which the Safavids were the better image-makers with strong mystical elements coloring their idea of rulership. In response to the Safavids' strong discourse on spiritual authority, the Ottomans created their own Sufi-Caliph imagery such as "the awaited mahd $\vec{\imath}$ " (rightly guided savior of Muslim community) and "quț" (axis mundi). Additionally, they designed their history and lineage to counter Safavid propaganda (pp. 256-60).

Existing scholarship on Islamic political thought mainly remains limited with pre-Ottoman times. The studies of Erwin I. J. Rosenthal, Antony Black, and Ann K. S. Lambton either ignored or played down political thought in the Ottoman Empire. In this regard, Yllmaz's study fills a major gap in the scholarship by showing both the continuity of intellectual trends from preOttoman times until the sixteenth century and the richness of Ottoman political thought. On the other hand, studies in Ottoman political thought have generally been restricted to nasihatnames (books of advice), which were mostly written by state officials, and a decline-based perspective, except for a few scholars such as Cornell H. Fleischer who interprets this genre as part of new state-making efforts and highlights the role of messianism in sixteenth-century political thought. Moreover, the survey of the primary sources that are related to political thought did not exist prior to the publication of Yllmaz's book or that of Marinos Sariyannis', titled, A History of Ottoman Political Thought up to the Early Nineteenth Century. In these matters, Caliphate Redefined is a valuable contribution to Ottoman intellectual history as well as to the history of political thought. Yilmaz expands the source base to include hitherto neglected genres and works such as gazavātnāmes (books of Raids), hagiographies, historical, theological, and juristic works. Along with introducing numerous texts, he also compellingly addresses the language of political thought through examining specific notions (khiläfat al-șūrì for temporal authority and khilāfat al-rahmmānī, al-rabbānī, ma'nawì, or haqiqi for spiritual rulership). In so doing, he successfully underscores the changes that took place in the balance of power between the Sufis and the state during the first three centuries of Ottoman rule.

Still, the author's treatment of the age of Süleyman as a uniform period, I believe, might overshadow some later transformations in the political, intellectual, and cultural life of the Ottomans. In this regard, the increased exposure of Rumi scholars to the scholarly traditions of Egypt and Syria following the Ottoman conquest of these lands, the decline of messianic expectations, 
and the increased weight of legalism in Ottoman courtly and learned circles after the end of the period of rapid expansion in the 1540s come to mind as changes that may have impacted the Ottoman conceptualization of rulership. Finally, I would like to make a minor correction. Even though Enisu'l'ārifin's author is identified as Şükrullah b. Ahmed (fl. 1464), because of a misattribution in the library catalogue, the text is actually a translation by Tācīzāde Ca fer Çelebi (d.1515); the original author is still unknown. ${ }^{2}$

To recapitulate, Caliphate Redefined is a masterly study that investigates the mystification of political authority as well as the politicization of Sufism in the post-Abbasid era with a focus on the Rumi lands in the Süleymanic age. It greatly enriches our understanding of Ottoman political thought. Given the ambitious scope of the study and the references to a wide array of authors, works, and concepts, the book will open new avenues of investigation not only for students of Ottoman studies, but also for Islamicists interested in post-Abbasid religious and political history.

Arif Erbil, M.A. Student Boğaziçi University Department of History

ORCID 0000-0001-9369-3034

DOI 10.26570/isad.650340

2 Kâtip Çelebi, Keş̧ü̉z-zunûn an esâmi'l-kütübi ve'l-fünün, ed. Rüştü Balc1, İstanbul: Tarih Vakfı Yurt Yayınları, 2007, I, 202; Emir Ca’fer Tugrầî, “Enîsüll-Arifîn Tercümesi” o6 Mil Yz A 3816, fols. $4^{\mathrm{a}}-5^{\mathrm{a}}$. 